\title{
Local seafood: rethinking the direct marketing paradigm
}

\author{
$\underline{\text { Joshua S. Stoll }}^{1}$, Bradford A. Dubik $^{2}$ and Lisa M. Campbell ${ }^{2}$
}

\begin{abstract}
Faced with strict regulations, rising operational costs, depleted stocks, and competition from less expensive foreign imports, many fishers are pursuing new ways to market and sell their catch. Direct marketing arrangements can increase the ex-vessel value of seafood and profitability of operations for fishers by circumventing dominant wholesale chains of custody and capturing the premium that customers are willing to pay for local seafood. Our analysis goes beyond a paradigm that understands direct marketing arrangements as solely economic tools to consider how these emerging business configurations create a set of conditions that can result in increased bonding and bridging capital among fishers by incentivizing cooperation, communication, and information production and organization. To build our case, we report on the economic value being generated for fishers in a cooperatively owned and operated direct marketing arrangement in eastern North Carolina. Over the course of 2 years, fishers participating in the Walking Fish communitysupported fishery received $33 \%$ more revenue for their catch compared to the average monthly ex-vessel price of finfish and shellfish landed in the surrounding region, and an additional $14 \%$ to $18 \%$ more per dollar by way of year-end profit sharing. We argue that these economic benefits create an incentive to participate, resulting in cooperation among fishers and increased communication skills that foster bonding and bridging capital that put fishers in a position to identify and respond to challenges that threaten the socialecological resilience of the systems within which they operate. We suggest that "institutional starters" like these can play a critical role in increasing the resilience of social-ecological systems, including fisheries.
\end{abstract}

Key Words: community-supported fisheries; direct marketing; institutional starters; local seafood; resilience; social capital

\section{INTRODUCTION}

The economics of fishing are changing (Olson 2011); no longer can fishers simply catch more to compensate for low ex-vessel prices (Kasperski and Holland 2013). With strict regulations (Hilborn 2012), depleted fish stocks (Jackson et al. 2001), rising operational costs (Garcia and Rosenberg 2010), competition with foreign imports (Pramod et al. 2014), and the privatization of resources (Lowe and Carothers 2008), many small-scale fishers are seeking new ways to partner with or bypass middlemen to sell their catch directly to consumers, restaurants, and wholesale buyers (Brinson et al. 2011). These direct marketing arrangements represent a promising new strategy for fishers as they attempt to reposition themselves, as both producers and dealers, in crowded and often highly competitive markets.

We provide an economic portrait of a direct marketing arrangement and describe how emerging business configurations like it provide a mechanism to increase social capital among fishers. We pay particular attention to a class of these arrangements called "community-supported fisheries" (CSFs). CSFs represent one of a variety of types of direct marketing arrangements that link fishers to consumers, restaurants, and wholesale buyers, e.g., schools and hospitals. We focus on the ways these arrangements incentivize cooperation among fishers and improve communication with individuals and organizations outside their immediate social networks, considering how the production of both bonding and bridging capital may enable fishers to respond to local problems that threaten socialecological resilience. With this framework, we seek to extend our analysis beyond a paradigm that understands these enterprises solely as economic tools to help fishers earn higher prices for their catch. The purpose of reframing this discussion is not to understate the economic value of direct marketing or dismiss the financial challenges that many fishers face, both of which are significant in the case we considered. Rather, our goal is to think more imaginatively about these nascent enterprises, exploring their broader relevance in achieving socioeconomic and ecological sustainability in fisheries.

We aim to bring focus to the interplay between CSFs and socialecological resilience, which we define as the capacity to withstand socioeconomic and ecological stresses without fundamentally shifting to an alternate and less desirable state (Walker et al. 2004), by describing how direct marketing arrangements can act as a type of "institutional starter" by fostering the emergence of nascent institutions that facilitate the production and mobilization of social capital toward improved social and ecological conditions. We make a distinction between direct marketing arrangements as a type of business practice and the social networks, rules, and norms that are formed and catalyzed through these arrangements. This delineation is consistent with the literature on new institutionalism that differentiates between institutions that are defined as the set of rules, procedures, social practices, and protocols that catalyze interactions between actors (Young 2002) and the organizations through which they are enacted (Ostrom 1990, Folke et al. 2007). Viewed through this lens, direct marketing arrangements themselves are not institutions. Rather, as we suggest, they are a business practice that creates a set of conditions that facilitates institutional emergence. These institutions, in this context social networks, rules, and norms, help to sustain business operations and position fishers such that they may be responsive to disturbances that threaten the viability of the systems within which they operate. Such disturbances include, but are not limited to, socioeconomic problems associated with low and volatile prices (Dahl and Oglend 2014), poor public perception about commercial fishing 
(Gelcich et al. 2014), and inequitable relationships between fishers and fish dealers (Wilson 1980), as well as ecological issues related to stock declines, bycatch, and habitat loss (Crowder et al. 2008).

The need for thinking about institutional starters arises out of the ongoing discussion on transformations in social-ecological systems (Westley et al. 2013). Transformability is "the capacity to create untried beginnings from which to evolve a new way of living when existing ecological, economic, or social structures become untenable" (Walker et al. 2004). Such transformation can occur at multiple levels and in multiple phases (Westley et al. 2013), although many suggest that crises and "jolts" often create windows of opportunity, an observation that is consistent with work by Holling and Gunderson (2002) on adaptive cycles (e.g., Greenwood et al. 2002, Biggs et al. 2010). Studying the mechanisms that spark transformation is viewed as a necessary step toward rebuilding underperforming, dysfunctional, and collapsed social-ecological systems (Olsson et al. 2004, Chapin et al. 2010, Westley et al. 2011). However, there is a relative lack of detail on the levers in these systems that dislodge inertia, motivate change, and cultivate capacity (Yu et al. 2014, although see Abernethy et al. 2014).

We use an exploratory case study approach (Yin 1984) to develop the concept of institutional starters. Using case studies allows for what McCarthy et al. (2014) describe as an "in-depth longitudinal understanding" that is largely missing from the literature on transformability, as well as in published literature on CSFs more generally. The published literature on CSFs is limited, particularly with regard to their broader implications as a social phenomenon and potential impacts on management (although see Brinson et al. 2011, Campbell et al. 2014, McClenachan et al. 2014). More fundamentally, the economic and noneconomic benefits of CSFs have yet to be described in detail. Our intent is to draw on the fine-grained knowledge of institutional dynamics afforded by a case study approach to develop a working model of the relationship between economic incentives, social capital development, and resilience, to be further refined and expanded as academic study of CSFs continues.

We build our case by focusing on the details of a direct marketing arrangement between fishers and consumers to lend depth to our analysis, using a CSF in eastern North Carolina, called Walking Fish (WF; see also Stoll et al. 2010, Campbell et al. 2014). Data from WF are used to quantify and describe the economic value that is incentivizing fishers to participate in the CSF. These data, coupled with 5 years of experience collaborating with and closely observing WF, elucidate, in practice, how direct marketing arrangements can cultivate social capital among fishers and better position them to act as institutional entrepreneurs (as described by Young 2002, Maguire et al. 2004, Rosen and Olsson 2013) able to actively identify and pursue context-specific strategies that address problems that threaten the social-ecological resilience of fisheries within which they operate. We begin with a brief description of the theoretical underpinning that supports our discussion.

\section{LINKING SOCIAL CAPITAL TO RESILIENCE}

Resilient social-ecological systems are those that can withstand impacts without undergoing structural or functional changes (Walker et al. 2004). Marine systems are particularly vulnerable to ecological flips that fundamentally alter the form and function of ecological systems as the result of anthropogenic stresses that have cascading effects that negatively impact the social and economic components of the systems (Ames 2004, Frank et al. 2011, Steneck et al. 2011). These shifts can be buffered against by actions that serve to maintain the integrity and complexity of these systems (Levin 2007). In fisheries, this includes protecting age and stock structure, habitat and water quality, and food web dynamics. Part of the challenge in managing these components in practice is that these systems are often highly heterogeneous and dynamic, making it difficult for managers to track conditions in a particular place from afar without having access to locally grounded information. This relationship between conservation objectives and information production creates an important link between the ecological and social components of a system. That is to say, because marine systems are complex, efforts to maintain ecological resilience can be aided by insights and ideas generated by those who are directly embedded in these systems. Such a dynamic has been observed in the American lobster (Homarus americanus) fishery in the Gulf of Maine, where commercial fishers have played a key role in providing information about the fishery that has led to the institutionalization of management strategies that have helped to sustain the industry and steward the resource (Acheson 2003). Conversely, there are also instances in which the disregard for these context-specific data resulted in management strategies that failed to maintain the ecological integrity of systems, as was observed in maritime Canada when inshore Atlantic cod fishers' knowledge about the resource was ignored by managers until the fishery was in crisis (Finlayson 1994).

In this way, although there is a strong tendency to think about fisheries conservation in terms of the biological and ecological components of the system, the social dimensions are often no less important to social-ecological resilience (Berkes 2009, Le Cornu et al. 2014). Indeed, the capacity for individual actors and organizations to adapt to and shape change is a key aspect of resilience in complex social-ecological systems (Berkes et al. 2006). Folke et al. (2010) make a distinction between "specific" and "general" resilience. Specific resilience refers to the ability of a system to tolerate a particular disturbance, whereas general resilience, as the term suggests, is about "coping with uncertainty in all ways." In this way, we can view general resilience as a more holistic conceptualization of resilience that aligns well with aspirations for socioeconomically and ecologically productive fisheries. Key to general resilience, which is the focus of our analysis, is responsiveness and adaptability. Responsiveness and adaptability in the context of fisheries can be in reference to both socioeconomic and ecological stressors. Various factors affect the extent to which responsiveness and adaptability exist, including individual and collective agency (Wijen and Ansari 2007, Coulthard 2012), leadership (Folke et al. 2005, Gutiérrez et al. 2011), and existing context (McCay 2002). Underlying all of these factors is the idea that for actors to be adaptable they must be able to mobilize information and resources at the appropriate moments. This depends, in part, on the social ties individuals have to each other. Thus, social capital can be considered a prerequisite for resilience (Olsson et al. 2004).

Social capital is the value derived from institutional arrangements and social bonds (Coleman 1988, Putnam 1995). Social capital can be subdivided into four categories: (1) relations of trust; (2) 
reciprocity and exchange; (3) common rules, norms, and sanctions; and (4) and connectedness, networks, and groups (Pretty and Ward 2001). These social interactions foster "bonding" within groups and "bridging" among groups (Woolcock and Narayan 2000). Bonding capital within groups facilitates joint learning, instills shared identity among actors, and lowers the cost of collaboration (Pretty and Smith 2004). Bridging capital, in contrast, facilitates knowledge exchange, innovation, and engagement with exogenous groups and resources (Lin 2002, Newman and Dale 2007). Both bonding and bridging capital are realized through social networks, themselves a type of institution. The lack of either type of social capital is thought to undermine effective management of social-ecological systems. For example, Holland et al. (2013) examine social capital in the Northeast Multispecies Groundfish Fishery using indices to quantify social capital among groups of fishers, called sectors. They hypothesize that the long-term viability and economic success of these selforganized, voluntarily formed entities are contingent on their ability to establish and maintain social capital in the future. In another case, Wilson et al. (2013) provide an interesting side by side comparative analysis of the lobster, groundfish, and sea urchin (Strongylocentrotus droebachiensis) fisheries, arguing that the ecological and regulatory context within which they are situated has facilitated the production of social capital in the lobster fishery while inhibiting its production in the latter two fisheries. Wilson et al. argue that it is this ability to generate social capital and act collectively that has led to the long-term sustainability of the lobster fishery and the destruction of the groundfish and sea urchin fisheries.

The relationship between social capital and social-ecological resilience is complex. It is dependent not only on the amount of social capital that exists, but also on the balance between bonding and bridging capital and on the interplay and feedback that occurs (Westley 1995). Indeed, how and in what ways these forms of capital are accumulated and configured within social-ecological systems influences how individuals and groups interact with one another and with natural resources (Bodin and Crona 2009, Barnes-Mauthe et al. 2015). For instance, high bonding capital and low bridging capital may limit the transfer and uptake of innovation from outside groups. Conversely, low bonding capital and high bridging capital can limit social cohesion, diminishing opportunities for collective actions (Bodin and Crona 2009). In these scenarios, social capital can constrain actors' ability to mobilize the resources necessary to adapt and respond to threats that can or are eroding the social and ecological dimensions of a system.

We argue that if social capital is tied to resilience in socialecological systems (Folke et al. 2005), then there is a need to bring focus to the mechanisms and types of arrangements that lead to institutions that produce and maintain the "appropriate" balance of social capital, particularly in situations in which general resilience is suspect, as is the case in many fisheries in North America and elsewhere (as illustrated, e.g., by Hennessey and Healy 2000, Steneck et al. 2013).

\section{RISE OF DIRECT MARKETING ARRANGEMENTS}

CSFs are one of the most visible and rapidly expanding types of direct marketing arrangements in North America, attracting attention because of their parallels to community-supported agriculture (CSA) farms (Campbell et al. 2014) and the ecological benefits they afford (McClenachan et al. 2014). Although CSA farms have operated in North America for more than 3 decades (Cooley and Lass 1998), CSFs are a relatively new phenomenon, first documented in Maine in 2007 (Libby 2011). There are now at least 40 active CSFs in North America, operating approximately 190 delivery locations in coastal communities (LocalCatch.org 2014), as well as ones in the United Kingdom, Chile, Italy, and Germany (M. Mesmain, 2014, personal communication; Fig. 1).

Fig. 1. Map of community-supported fisheries delivery locations in North America (LocalCatch.org 2014).

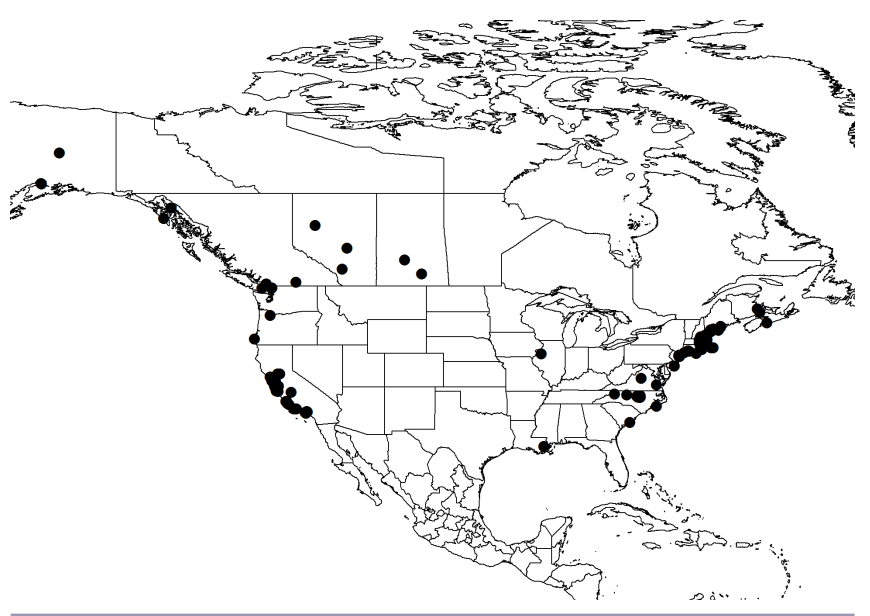

The rise of direct marketing arrangements is partly a reflection of consumers' growing demand for the social, ecological, and economic value of local foods and associated terroirs (Kloppenburg et al. 1996, O'Hara and Stagl 2001). Indeed, direct marketing arrangements for seafood are being touted in popular media as among the "hottest" food trends (e.g., Greenberg 2014). However, it is not just consumer demand that is driving their emergence; these arrangements are also being driven by the fishing sector in an effort to reform the existing seafood economy and more effectively integrate seafood into local food systems (Olson et al. 2014). This push to relocalize seafood markets hints at the socioeconomic and ecological externalities caused by the globalization of fishing fleets and seafood markets, which have led to widespread overexploitation of marine resources (Berkes et al. 2006).

Each direct marketing arrangement is implemented differently, conforming to locally specific social, economic, and ecological factors. CSFs differ in size, ranging from a few dozen participants to upward of a thousand (LocalCatch.org 2014; J. S. Stoll, unpublished data). The logistical structures include instances in which customers meet fishers to pick up seafood on their docks, subscribers receive seafood by mail, or subscribers pick up shares at "drop-off" locations several hundred miles away or even in other states or provinces. Port Clyde Fresh Catch (based in Maine, USA), for example, has offered shares to subscribers in Blue Hill, Rockland, and other nearby communities in Maine and has also shipped shares to consumers in other states. In contrast, the operators of Abundant Seafood sell shares of snapper and grouper directly off a pier in Charleston, South Carolina, where 
their boat, F/V Amy Marie, is docked. McClenachan et al. (2014) report that the average distance seafood is distributed through a CSF is $65 \mathrm{~km}$, considerably less than the $8812 \mathrm{~km}$ they determined industrially sourced product travels. CSFs also differ in terms of the species composition offered and in the way shares are prepared and processed. Core Sound Seafood, a North Carolina-based CSF, has offered its subscribers well over a dozen species, whereas the operators of Alaskan's Own sell only a few species. Such variability is tied to both the local availability of seafood and the fishers that participate in a given CSF. Weather conditions; regulatory constraints, e.g., seasonal closures and catch limits; and health and safety considerations also affect the amount of variety offered through a CSF. There is also variation in the legal and organizational structure of direct marketing arrangements like these. Existing CSFs are owned and operated by individual fishing families, coordinators, cooperatives, processors, and seafood dealers. Skipper Otto's CSF in Vancouver, British Columbia, Canada, is a small-scale, family-owned and operated CSF that focuses on salmon and other species caught in northern British Columbia. In contrast, Cape Ann Fresh Catch is owned and operated by the Gloucester Fishermen's Wives' Association in partnership with a local processor, fishers, and staff.

Our focus is on the subset of these entities that involve collaboration among fishers. The structural and material diversity of CSFs has not been explored previously, but this diversity is not surprising given that CSFs are a relatively new phenomenon and experimentation is often associated with emergent forms of innovation (Holling and Gunderson 2002, Westley et al. 2011). Despite the nuances that differentiate each CSF, as we describe subsequently, the fundamental mechanics of CSFs are largely similar. Thus, even though the variability observed among CSFs will have a direct bearing on how these arrangements are operationalized, we contend that these differences do not diminish CSFs as a meaningful analytic category.

\section{BUILDING A CONCEPTUAL MODEL}

We put forward a conceptual model that describes direct marketing arrangements as mechanisms for the production of bonding and bridging capital, rather than solely as tools for economic development. Our model starts with economic incentives, recognizing that the economic potential associated with these direct marketing arrangements is an important element of their proliferation.

\section{Economic incentive leads to participation}

Many small-scale commercial fishers are under increasing pressure to find ways to earn more for their catch. Direct marketing arrangements have the potential to increase the amount of money fishers earn for their catch (see Brinson et al. 2011 and the data we present). Not only can fishers earn higher up-front prices by bypassing or developing new partnerships with middlemen, but they can also benefit from additional economic draws such as end-of-year profit sharing, health care subsidization, and cash advances to purchase and repair gear (National Summit Planning Committee 2012). The particulars of these economic benefits will differ between CSFs, but in all cases, these benefits create an incentive for fishers to participate.

\section{Participation leads to cooperation}

One of the challenges that fishers face in sustaining CSFs is being able to satisfy subscribers' demand for variety, i.e., multiple types of seafood (Campbell et al. 2014). This challenge is not unique to fisheries. Indeed, farmers must also provide a diverse array of vegetables to their CSA members (Perez et al. 2003). However, it is often more difficult for a fisher to supply consistent variety than it is for farmers because of the nature of their occupation, i.e., farmers can plant in ways that maximize variability. Fishers, unlike their agricultural counterparts, cannot seamlessly shift between fisheries or necessarily harvest a wide range of species because they are constrained by regulations, access to quota, licensing requirements, and the cost and time involved in switching gears. Thus, the advantages of specializing as an individual fisher create a codependence among fishers in CSFs; to meet and sustain market demand, fishers need to work together to obtain, accumulate, and supply their market with a consistent and diverse range of products. To fulfill orders, fishers must also coordinate to process and distribute product.

\section{Cooperation creates bonding capital through information management}

The need to meet subscribers' demands, e.g., by providing variety, quality, and freshness, creates an incentive for fishers to work together, but it does not necessarily ensure prolonged cooperation among fishers. Indeed, working collaboratively creates opportunity for conflict. Tensions can arise for any number of reasons, ranging from the resurfacing of prior arguments to disagreements over marketing strategies. Tensions can also arise over economic matters related to managing operational costs that affect the prices fishers earn for the catch, the percentages of profits members receive, and the fixed costs such as coordination, processing, or transportation. These conflicts have the potential to undermine cooperation, thereby negatively affecting the ability of CSFs to function effectively. To hedge against this potential risk, operational rules are devised that establish agreed upon boundaries and make expectations explicit (Young 2002). These rules, like social networks, are a type of institution. Within the context of direct marketing arrangements, these rules might relate to the amount of seafood fishers will contribute to the CSF or how ex-vessel prices are established and profits are distributed. These rules can only be enforced if accurate and detailed information about the CSF is maintained. Without this information, fishers might suspect cheating, such as inequitable allocations of year-end profits. Thus, information collection and organization not only is necessary to manage daily business operations, but also serves as a strategy for maintaining trust and sustaining and building bonding capital among fishers. The same level of data collection and management is not necessary for individuals that operate independent businesses. Even if it makes good business sense to maintain these records, doing so does not directly affect their relationships with other fishers or have an impact on other fishers' earnings.

\section{Communication creates bridging capital through engagement with outsiders}

Through direct marketing arrangements, fishers must regularly and effectively communicate with subscribers to convey information about their catch, openly discussing topics related to seafood, marine conservation, and management. Subscriber communication represents a departure from tradition. Where in the past fishers may have sold their catch to an increasingly limited number of fish buyers, i.e., middlemen, CSFs provide an opportunity for fishers to sell to hundreds if not thousands of individuals directly. Communicating with subscribers is not like 
communicating with fish buyers or other fishers that live and work in the industry and have a tacit understanding of "how things work." Rather, subscribers are often "outsiders" with different and sometimes conflicting values. Communicating with this sector means that fishers need to translate what, why, and how they catch seafood into a lexicon that is both understandable and tractable to their audience. This requires a set of skills that is not necessary for running a commercial fishing vessel, catching fish, or selling to a local fish buyer. Not only does it often involve effective use of social media and e-mail, which in some cases is unfamiliar territory for fishers, it also means honing messages and learning to effectively promote aspects of their businesses, such as low-impact fishing practices and local production, that resonate with subscribers and potential subscribers. This is an iterative learning process, but one that is necessary for maintaining subscriber participation.

The benefits gleaned from regular and repeated communication with subscribers does more than help fishers sustain their market. Regular interaction with subscribers leads to experience translating complex and often contentious issues for nonexperts that have limited knowledge and expertise in commercial fishing. Such proficiency is not only helpful in attracting and maintaining a customer base; it is also useful in establishing bridging capital with other outsiders, such as fisheries scientists, managers, policy makers, media, and granting agencies.

\section{Social capital fosters opportunity to increase resilience}

The capacity to sustain and cultivate cooperation among fishers and to communicate with outsiders can enable CSF operators to work collectively to pursue other opportunities such as building markets, expanding clientele, and taking on and addressing nonmarket challenges that threaten the social-ecological systems within which they are embedded. Such agency and ability to be adaptive is a cornerstone of general resilience and a key to sustaining the social and ecological components of dynamic systems such as those associated with marine resources (Folke et al. 2010, Westley et al. 2011). We bring this conceptual model together in Figure 2, illustrating how CSFs represent a type of institutional starter that can build capacity among fishers and mobilize social capital in ways that contribute to the socialecological resilience of systems.

To summarize, fishers are drawn to CSFs to earn more money for their catch to offset the low ex-vessel prices that they receive from fish dealers. In joining, fishers must develop a set of rules to manage the internal operations of these businesses and simultaneously hone their communication skills so that they can effectively engage with and maintain customers. These processes lead to the production of bonding and bridging capital that has utility that extends beyond the relatively simple task of aggregating and distributing seafood. Specifically, bonding capital facilitates collective action, and bridging capital fosters access to new ideas and external resources. It is this combination of social capitals that is directly relevant to increasing socialecological resilience. By being able to work collectively and gain access to new resources and new ideas, fishers may be able to overcome two common obstacles. First, the lack of cooperation among fishers often impedes efforts to develop a shared understanding of the cause of social and ecological disturbances or envision, implement, and enforce rules that support sustainable resource management (Wilson et al. 2013, Acheson and Gardner 2014). The production of bonding capital addresses this problem by making it easier for stakeholders to work together. In this way, bonding capital acts as a precursor to collective action. Such collective action will not be inherently conservation oriented, but there are enough instances in which collective action among natural resource users has led to improved ecological conditions or the sustainability of these resources that it is not outside the range of possibility (e.g., Cudney-Bueno and Basurto 2009). Second, small-scale fishers often, but not always, lack a surplus of resources to experiment with innovative strategies for improving their operations or reducing unnecessary impacts on the resources (Tietze and Villareal 2003). Thus, fishers' ability to access external resources, including funding, research, and technical assistance, represents an important way to operationalize locally generated and locally grounded ideas about how to improve the ecological system within which they operate, such as how to address particular bycatch problems, the timing of temporal closures, or the placement of spatial boundaries to reduce environmental impacts. Access to these resources may be aided by increased bonding capital that is derived by communication with outside individuals and organizations.

Fig. 2. Conceptual model depicting the interplay between direct marketing arrangements and social capital. Fishers are initially drawn to community-supported fisheries (CSFs) as a means to earn more for their catch (thick black arrow). The economic incentive, combined with the structure of CSFs, can create a set of conditions that foster bonding and bridging capital (gray arrow). The social networks through which this social capital is produced and the rules and norms created to sustain and manage this social capital represent new institutions. Roman numerals correspond to each component of the model: (i) economic incentive leads to participation; (ii) participation leads to cooperation; (iii) cooperation creates bonding capital through information management; (iv) communication creates bridging capital through engagement with outsiders; and (v) social capital fosters opportunity to increase resilience.

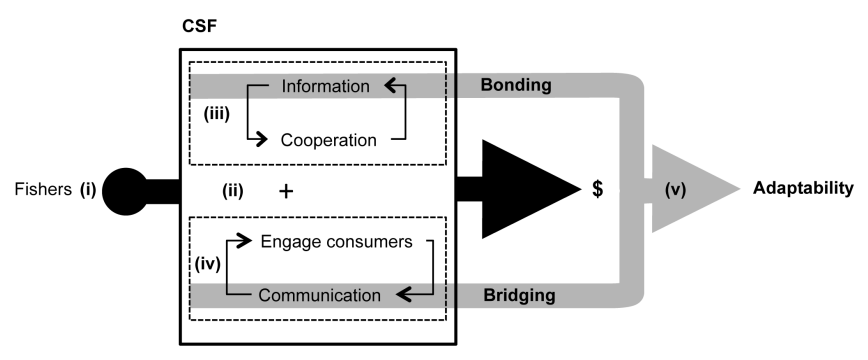

\section{CASE STUDY}

To more fully elucidate the relationship between direct marketing arrangements, institutional emergence, social capital production, and social-ecological resilience, we focus on a case study in North Carolina (USA). It is structured such that it follows the same format of the conceptual model, starting with a description of how the economic potential of the direct market arrangement has incentivized participation and ending with consideration of the link between the operation and social-ecological resilience. The first four sections of this case study are supported by quantitative 
and qualitative data, whereas the discussion about socialecological resilience is more speculative. Although it builds off of concrete examples, our discussion about social-ecological resilience is inherently more theoretical because we do not yet have enough data to know with any certainty if the efforts by the CSF will result in meaningful ecological change.

WF is a direct marketing arrangement based in Carteret County at the southern extent of the barrier island chain known as the Outer Banks. WF is a cooperative that owns and operates a CSF that delivers shares of fresh, locally caught seafood to subscribers in the urban center of the state (Campbell et al. 2014). In the WF CSF, subscribers purchase a share for a 12-week season and, in doing so, agree to "take what they get" in their CSF cooler at each delivery. Shares of seafood cost subscribers between $\$ 114$ and $\$ 516$, depending on the quantity of seafood, frequency of delivery, and type of processing, i.e., headed and gutted or filleted.

Although WF owns and operates the like-named CSF, the CSF actually preceded the cooperative. Duke University graduate students studying at the Nicholas School of Environment initiated WF in 2009 in partnership with fishers and several locally based for-profit and nonprofit organizations to see if the CSF model could work in North Carolina. After 2 years of operations, the CSF transitioned to the participating fishers, a processor, and support staff that is paid through the income generated by the sale of seafood. WF filed articles of incorporation and bylaws with the state of North Carolina and the federal government in the winter of 2010 and became a marketing cooperative in January 2011. The cooperative, which started with five members, has three membership classes composed of employees, processors, and fishers. Each ownership class is represented on the board of directors and receives a proportion of profit as specified in its bylaws. It is the only fishers' cooperative in Carteret County. The profit fishers receive is distributed among individuals based on the value in dollars of seafood each fisher sells to the cooperative. This rule and others are negotiated by the board of directors and implemented through a detailed agreement that is updated and signed before each season.

We focus on WF during its initial 2 years as a nascent cooperative, from January 2011 to December 2012. We first describe the economic gains made by the cooperative, using price premiums as a proxy for the value created from the CSF. Price premiums were derived by comparing WF prices, i.e., the prices that the cooperative paid to its members for finfish and shellfish, to the average monthly ex-vessel prices of seafood in Carteret County and the adjacent counties of Craven, Onslow, and Pamlico. The multicounty (regional) data were derived from reporting data that licensed seafood dealers voluntarily submitted to the North Carolina Division of Marine Fisheries (DMF). These data were supplied to us in anonymized electronic format by DMF. Most data were reported in U.S. dollars per pound; those that were reported by number or bushel were converted to U.S. dollars per pound by DMF. In total, we calculated price premiums for 21 of the 28 species of finfish and shellfish sold through the cooperative, accounting for $98 \%$ of the seafood (by value) sold by WF. To calculate these values for each species and in total, we determined the differences between the WF prices and the multicounty (regional) monthly average for each pound of seafood sold through the CSF and then weighted these values by the total poundage of each transaction to derive a weighted average price premium for each species. Taking this approach allowed us to account for seasonal price variability and adjust for differences in prices across species that would otherwise skew the results. Microeconomic data like these have not yet been described in the literature.

We discuss how these economic benefits served to incentivize cooperation and have since helped to spur collective action by WF to address issues relating to the social-ecological resilience of the immediate community. Data on the latter are descriptive, derived through participant observation and regular engagement with the cooperative from 2009 to 2014 . J.S.S. worked closely with fishers and other community representatives to start WF and to set up its cooperative structure from 2009 to 2011 and has since provided technical support as requested. B.A.D. has worked with WF since the summer of 2013, developing a short documentary film and assisting in an ongoing working waterfront development project. L.M.C. has served as faculty adviser to students involved in WF and has helped to maintain a connection between WF and Duke University. All these experiences allow us to practice "observant participation" (Brewer 1994), both on how WF has evolved and matured, and how it fits and is perceived within the broader socioeconomic landscape.

\section{Economic incentive leads to participation}

The cooperative operated 3 seasons per year (winter, spring, and fall) during the 2-year period in which price data were shared. In year 2 , the cooperative made $12 \%$ more deliveries $(n=35)$ compared to year $1(\mathrm{n}=31)$. During this period, WF supplied 28 different species, including lesser known and underutilized species like jumping mullet (Mugil cephalus) and sheepshead (Archosargus probatocephalus). By percentage, hard clams (Mercenaria mercenaria), flounder (Paralichthys dentalus, $P$. lethostigma, and P. albigutta), and shrimp (Farfantepenaeus duorarum, F. aztecus, and Litopenaeus setiferus) made up the greatest proportion of seafood delivered to customers in both years (Table 1). The weighted average price premium of all species purchased from cooperative members was 33\% during the 2-year period (Table 2). Price premiums varied considerably across species but were never lower than the average ex-vessel prices in the region, ranging from $5.8 \%$ to $185 \%$ above the regional averages. Generally, lower value species had higher price premiums than higher value species. For example, the price premium for jumping mullet (M. cephalus) ranged from $89 \%$ to $127 \%$ with an average weighted price premium of $114 \%$ (Table 2). Although there is a market for jumping mullet roe in Asian markets, and local prices tend to spike in the late summer and fall when the fish have a high roe count, the average ex-vessel price of jumping mullet did not exceed $\$ 1$ per pound during the 2-year period. Therefore, an increase in ex-vessel price for jumping mullet represents a much larger increase in percentage than the same increase in the price for a higher value species like gray triggerfish (Balistes capriscus) or red grouper (Epinephelus morio). For these species, the weighted average price premium was $24 \%$ and $6 \%$, respectively. 
Table 1. Summary of community-supported fisheries in year 1, year 2 , and combined. The number of deliveries increased in year 2 , whereas the number of species delivered decreased.

\begin{tabular}{lccc}
\hline \hline & 2011 & 2012 & Total \\
\hline Deliveries & 31 & 35 & 66 \\
Species & 25 & 22 & 28 \\
Top 3 & Hard Clams, & Hard Clams, & Hard Clams, \\
& Flounder, & Flounder, & Flounder, \\
& Shrimp & Shrimp & Shrimp \\
\hline
\end{tabular}

In addition to price premiums earned on seafood sold to the CSF, overall profits earned by WF were distributed by way of dividends paid to cooperative members at the end of year 1 and year 2, adding to the overall value of the CSF to members. Year-end profits were distributed to fishers based on the amount of seafood (by value) individuals sold to the CSF during the course of each year. Fishers that contributed larger amounts of seafood received a larger proportion of the profit than those that did not contribute as much product. This approach rewarded participation and was established to prevent free riders from benefiting from other members' contributions. Profit margins fluctuated from year 1 to year 2, decreasing slightly from a $\$ 0.18$ dividend per dollar of seafood sold to the cooperative in year 1 to $\$ 0.14$ per dollar in year 2. We do not report absolute dollar values of profit or endof-year dividends to protect proprietary information of the cooperative.

Several members in the cooperative also received short-term, nointerest loans and outright payment for equipment or repairs on equipment. During the 2-year period, 2 loans were given to fishers to purchase new pound nets for flounder fishing. In both instances, these loans were repaid within 6 months with seafood supplied to the CSF. The cooperative also made 2 direct payments to repair equipment or purchase new gear. In the first instance, money was given to a fisher in the cooperative for repairs to a refrigerated truck. In the second case, the cooperative purchased $20 \mathrm{crab}$ pots for fishers to replace those that were destroyed by loggerhead sea turtles (Caretta caretta), using money earned from a special marketing campaign. CSF subscribers were given information about the situation and asked to buy a trap for a fisher. In exchange for purchasing a trap, the CSF subscribers received 3 dozen blue crabs (Callinectes sapidus) and a handwritten thank-you card from the cooperative. This exchange resulted in a combination of benefits. First, consumers benefited from the transaction by gaining access to fresh blue crabs on a regular basis over the course of the season. Second, fishers benefited by receiving money to purchase new crab pots. There is also arguably a third (indirect) benefit that has relevance to the discussion about ecological resilience. Loggerhead sea turtle interactions in North Carolina are a source of ongoing tension because they are listed as endangered under the U.S. Endangered Species Act (Boucquey et al. 2012, Campbell et al. 2014). The basic problem has been that as sea turtle abundance has increased in the region, gear interactions are becoming less avoidable. This situation has been particularly problematic in the large-mesh gill net fishery for flounder, where entanglements have led to multiple closures. These closures have added another layer of economic hardship to local fishers, many of whom have historically depended on the gill net fishery (Campbell et al. 2014). The cooperative's effort to raise money to buy crab pots does not help to solve the gill net problem, but it does act to support an alternative fishery that does not have the same impact on sea turtles; if anything, the pot fishery may benefit turtles by making a food source, e.g., blue crabs, more accessible. In this way, the cooperative's crab pot exchange served to cultivate general socialecological resilience by supporting a system in which both fishers and sea turtles can coexist.

The cooperative also benefited those providing services to the CSF. These included paying a member of WF to transport seafood to Raleigh and Durham, about a 3-hour drive from the coast. In addition, the cooperative hired a coordinator to oversee sales, education and outreach activities, and website maintenance. The cooperative also paid a local retail business to provide processing, storage, and waste removal services. Through the cooperative's investment in the local retail business, the owner was also able to expand, hiring a full-time salaried employee, and make several improvements to the facility. The coordinator and the processor are members of the cooperative and receive a share of the endof-year profit.

\section{Participation leads to cooperation}

WF grew its membership modestly during the 2-year period, expanding from 5 members in January 2011 to 12 members in December 2012. The upward trajectory was a reflection of the cooperative's efforts to gain access to a broader and more diverse range of species. In North Carolina, the geography is such that commercial fishers can exploit a wide range of inshore and offshore species. However, even in North Carolina where there are a multitude of species and fishers can still shift between fisheries relatively easily with a single general category license, compared to places where there are more limited entry programs that limit access, fishers tend to be somewhat specialized; offshore fishers tend to predominantly fish offshore, whereas the inshore fleet stays in the shallow water sounds or near shore. This pattern is reflected in the WF data, in which the most species an individual fisher contributed to WF was 12, with the mean being 3.6 and the low being 1 . Thus, to meet customer demand for variety, WF had to actively solicit new fishers to join the cooperative. In particular, it targeted fishers who could supply species that other members in the cooperative did not already target or who could target them at different time periods because they used a different gear type.

Joining WF has meant more than simply reaping the benefits of the price premium and profit sharing associated with the CSF. It has also involved becoming a member of a new social network geared toward sustaining and growing the CSF. The responsibilities associated with being part of this network have continually evolved as rules and directions for the CSF are proposed, tested, adopted or rejected, and refined. Both rules and directions have come from founding members of the CSF and newer members, particularly those most actively involved in daily operations. These rules were specified in an operational plan that was developed each season. Having a system in place to document and refine rules and strategies allowed the cooperative to experiment with new marketing strategies and be explicit about how to move forward with contested decisions. For example, after months of negotiation, the board of directors voted to start a 
Table 2. Price premiums for 21 species of seafood sold through Walking Fish relative to the average monthly ex-vessel prices in the region. "All" category denotes seafood purchased from members and nonmembers of the cooperative. "Members" category denotes seafood purchased from individuals in the cooperative only. "All" category is higher than the "members" category because a portion of the seafood purchased from nonmembers was from local fish houses. Buying seafood from a fish house costs more than buying seafood from a fisher because these businesses act as middlemen in the supply chain. Note: price premiums were not calculated for oysters or blue crabs (soft) because data were either incompatible or unavailable.

\begin{tabular}{|c|c|c|c|}
\hline Species & Scientific name & All & Members \\
\hline Blue Crab (Hard) & Callinectes sapidus & $185 \%$ & $185 \%$ \\
\hline Blue Crab (Soft) & Callinectes sapidus & NA & NA \\
\hline Bluefish & Pomatomus saltatrix & $78 \%$ & $78 \%$ \\
\hline Clam, Hard (numbers) & Mercenaria mercenaria & $77 \%$ & $77 \%$ \\
\hline Cobia & Rachycentron canadum & $49 \%$ & $18 \%$ \\
\hline Drum, Red & Sciaenops ocellatus & $42 \%$ & NA \\
\hline Flounders & Paralichthys dentalus, $P$. lethostigma, $P$. albigutta & $29 \%$ & $26 \%$ \\
\hline Grouper, Red & Epinephelus morio & $6 \%$ & $6 \%$ \\
\hline Mackerel, King & Scomberomorus cavalla & $27 \%$ & $27 \%$ \\
\hline Mackerel, Spanish & Scomberomorus maculatus & $31 \%$ & $22 \%$ \\
\hline Mahi-Mahi & Corypaena hippurus & $21 \%$ & $21 \%$ \\
\hline Mullet, Sea & Menticirrhus americanu & $66 \%$ & NA \\
\hline Mullets, Jumping & Mugil cephalus & $110 \%$ & $114 \%$ \\
\hline Oyster (bushels) & Crassostrea virginica & NA & NA \\
\hline Sheepshead & Archosargus probatocephalus & $124 \%$ & $122 \%$ \\
\hline Shrimp (head on) & $\begin{array}{l}\text { Farfantepenaeus duorarum, F. aztecus, Litopenaeus } \\
\text { setiferus }\end{array}$ & $29 \%$ & NA \\
\hline Snapper, Pink & Pagrus pagrus & $26 \%$ & $12 \%$ \\
\hline Snapper, Vermilion & Rhomboplites aurorubens & $18 \%$ & $17 \%$ \\
\hline Spot & Leiostomus xanthurus & $37 \%$ & $52 \%$ \\
\hline Triggerfish, Gray & Balistes capriscus & $28 \%$ & $24 \%$ \\
\hline \multirow[t]{2}{*}{ Trout, Gray } & Cynoscion regalis & $24 \%$ & $51 \%$ \\
\hline & Weighted Average & $41 \%$ & $33 \%$ \\
\hline
\end{tabular}

CSF delivery in the county where WF is based. This was not an easy decision because several members were concerned that it would create competition with local seafood dealers, including the processor involved in WF. Having decisions like this documented in the operational plan provided a way for the cooperative to progressively coadapt management strategies and responsibilities and sustain cooperation among members.

\section{Cooperation creates bonding capital through information management}

Information that WF collected to manage its operations appears to have played an important role in enabling the emergence of bonding capital among its members. To understand this relationship requires a basic understanding of the cooperative's operating agreement. WF supplemented its bylaws with an operating plan that provides detailed information about the roles and responsibilities of cooperative members. During the corresponding 2-year period, the operational plan was reviewed, amended as necessary, and signed by the board of directors prior to the start of each of the 6 seasons it executed. The information specified in the operational plan represents an attempt on the part of the cooperative to articulate a set of rules that are transparent and fair. Many of these rules deal with pricing, profit sharing, and other economic issues. The operational plan also described and delegated responsibilities to members of the cooperative for the different aspects of the CSF from processing to correspondence with customers to transportation. Some of the rules and responsibilities outlined in the plan can be easily enforced because it is relatively simple to determine whether they are being complied with on a regular basis. For example, it takes minimal effort to figure out if someone is doing a poor job cleaning fish or if deliveries to subscribers are not occurring smoothly, because customers are quick to respond via e-mail expressing concern. However, this is not the case for all rules. Indeed, some of the most important rules, i.e., those that have direct financial implications for fishers, are difficult to monitor, creating the potential for suspicion and opportunities for cheating that can undermine cooperation and unravel the bonding capital derived from working together to execute the CSF. For example, each fisher may be able to keep track of the amount of seafood he or she contributed to the CSF but cannot easily monitor the proportion of catch he or she contributed relative to other fishers during the course of a particular season. Therefore, it is difficult to know with certainty how much of the year-end profit, calculated by proportional contribution, a fisher should receive. WF has sought to ameliorate this risk by maintaining detailed information about its operations, tracking each pound of product from boat to consumer. By keeping these detailed records about when seafood was caught and by whom, where it was landed and with what gear, how much was sold and for what prices, what it cost to process and transport, and what subscribers thought about it, WF has the ability to retrace each transaction. These detailed records were not the only way fishers were able to maintain and build bonding capital, but they facilitated group cohesion by reducing the need for each fisher to be suspicious of other members of the cooperative or worry that he or she would not receive a fair portion of the profit. 


\section{Communication creates bridging capital through engagement} with outsiders

WF consistently communicated with a few thousand people per week through social media and e-mail during the 2-year period and attracted untold others to its website. Most of this correspondence was with customers based outside Carteret County within the state's urban hub where its CSF delivery locations were based. Fishers in the cooperative also directly interacted with people during educational events that they hosted or were invited to attend. These events are chronicled on the cooperative's website and ranged from speaking engagements at Duke University to an art exhibit and auction it hosted in Beaufort. The focus of these communications was often to promote upcoming sales or notify customers about the week's seafood. Through these routine exchanges, WF regularly fielded comments, questions, and concerns that ranged from fears from anxious customers about how to clean the blue crabs that they received to more critical comments about the real and perceived impacts of certain gear types. Customers even periodically approached WF with business propositions relating to ways to sell more seafood or create new products with waste from bycatch or processing scraps. These exchanges were typically facilitated by the cooperative's paid coordinator, who would receive the initial e-mail or phone call and then direct it to the appropriate cooperative member. No matter how pedestrian or how complex the topic, each response represented an opportunity to gain proficiency conveying information about the CSF and the seafood WF harvested.

The experience gained from these exchanges has no doubt proved helpful in engaging with other audiences outside of Carteret County and the immediate fishing sector because these communication skills are transferable. Indeed, as the result of WF's visibility, the cooperative also had opportunities to engage with and forge relationships with a range of people and organizations across the United States. For example, the cooperative was invited to participate in the Capitol Hill Ocean Week in Washington, D.C.; a Regional Fishery Management Council contacted the cooperative to request information; the cooperative was invited to attend a national conference on CSFs; graduate students and faculty from colleges and universities across the United States probed the cooperative for data; and media outlets from coast to coast periodically requested interviews and sound bites. These opportunities enabled WF to share its story and build bridging capital with nonprofit organizations, private investors, other fishers, and fisheries scientists and policy makers.

\section{Social capital fosters opportunity to increase resilience}

\section{Increasing socioeconomic resilience}

WF provides a suite of economic benefits to its members, including higher ex-vessel prices and profit sharing. Inasmuch as these benefits correspond to improving the well-being of the cooperative's members and helping fishers diversify the ways that they can get their catch to market, WF can be seen as contributing to socioeconomic resilience. WF may also serve to strengthen social resilience more broadly by working to improve the public perception of commercial fishing in North Carolina, using the weekly delivery of seafood as a platform to engage consumers and their followers on Facebook and Twitter in discussions about the industry and fisheries more broadly. By forging these connections, WF is cultivating a new base of nontraditional advocates that may ultimately ally themselves with the commercial fishing sector when it comes to normative public policy decisions about resource allocation and access that threaten to undermine the socioeconomic viability of fishers. This is a particularly important issue in North Carolina where there is a highly politicized campaign underway to reallocate marine resources to the recreational angling sector. Through this effort, there have been attempts to ban particular commercial fishing practices and designate species like red drum (Sciaenops ocellatus) as "recreational," meaning that they can only be caught and landed by recreational anglers.

\section{Increasing ecological resilience}

There are also a variety of ways that WF has sought to reduce the environmental footprint of its operations. For example, the cooperative has experimented with different ways to utilize the fish scraps that are generated from processing seafood for each week's delivery. Strategies have ranged from giving it to fishers to use as bait in the blue crab pot fishery to hauling it to a local organic farm to use as fertilizer. These efforts have also been complemented by attempts to more fully utilize whole fish for food by exposing consumers to different parts of fish, e.g., fish heads, row, "gizzards," and even skins. There may also be an ecological benefit from the relatively short distance that the seafood is distributed (maximum: $290 \mathrm{~km}$ one way). Although WF distributes its product over a greater distance than the average CSF reported by McClenachan et al. (2014), this distance is much less than the distance most seafood is transported. Further, WF has in the past purchased carbon credits to offset the carbon footprint associated with this distribution (Stoll et al. 2010). These strategies are complemented by how WF has sourced seafood for the CSF. As evidenced by the data we have discussed, WF has consistently supplied consumers with a diverse range of species. This has including using underutilized species as well as bycatch. This approach aligns well with the view that fisheries impacts can be muted by diffusing impacts across fisheries and the marine environment (Zhou et al., in press), rather than depleting particular species in particular locations and then moving on (Berkes et al. 2006). In this way, broadening the portfolio of species on which fishers can draw provides greater flexibility for fishers while at the same time decreasing the impact on any one particular fish stock.

Increasing social-ecological resilience

All of the aforementioned actions can be linked to increased social or ecological resilience of the system within which WF is situated. However, to limit the discussion to these activities is to restrain our analysis of the interplay between direct marketing arrangements and their potential to cultivate general socialecological resilience. Resilience is often achieved by what Westley et al. (2013) describe as a "deft mobilization of energy" at multiple scales. "Deft mobilization" implies both efficacy, i.e., deftness, and action, i.e., mobilization, in response to social-ecological disturbances. The bonding and bridging capital that has been produced by WF and the emergent institutions that have both enabled and helped to sustain this social capital have created opportunities for WF to identify problems and mobilize resources to pursue a range of initiatives. In this way, WF is becoming a type of institutional entrepreneur. By this we mean that the CSF 
has become a "gateway" for the cooperative, leading to new complementary endeavors that serve fishers in the cooperative and the broader community. We see this in the way WF has expanded its markets and in how it has invested in projects that extend beyond the economic dimensions of fisheries, touching on other key elements of the social-ecological system that are ultimately critical to sustaining the long-term viability and resilience of fisheries. This active pursuit of opportunities is perhaps most evident in WF's emerging focus on cooperative research.

WF's first collective foray into cooperative research dealt with monitoring contaminants in seafood. The research was motivated by subscribers' concerns about the healthfulness of the seafood they were getting through the CSF. Much of this concern stemmed from the ubiquitous educational seafood cards that classify certain species as unsustainable or unhealthy because of pollutants (as described by Stoll and Johnson 2015). One of the species listed on several of these cards is blue crab, the largest and most economically important fishery in North Carolina. Indeed, the Food and Water Watch listed blue crabs as one of the "dirty dozen" based on elevated levels of PCBs found in samples taken from sites off the coast of Texas and Georgia. Concerned both that these data did not accurately represent the pollutant levels of blue crabs in North Carolina, and, if they did, that something needed to be done to address the issue, a fisher in the cooperative worked with Duke University to develop a proposal to study pollutant levels of blue crabs and a variety of other inshore species (Freitag et al. 2012). This research, which eventually expanded to included partners at North Carolina State University and North Carolina Sea Grant, came about because fishers in the cooperative wanted to maintain bridging capital with subscribers who wanted to be sure the seafood they were eating was safe, and this was possible because WF had previously forged bridging capital with researchers at Duke University. Results from this research showed that the pollutant levels in blue crab, and the inshore fisheries that were analyzed in the study, do not pose a health risk (Freitag et al. 2012).

Since this project, WF has pursued a range of different projects as a group and individually. Some of these efforts have been funded or supported with in-kind support from entities like Duke University and North Carolina Sea Grant, whereas others, like the development of bycatch avoidance gear for sea turtles in the large-mesh gill net flounder fishery, have not yet attracted external partners. However, this has not deterred WF from moving toward a broader and more ambitious cooperative research agenda. Looking for ways to build on the success of the CSF and expand further, WF is in the process of pursuing several capacity-building projects. Most notably, the cooperative recently embarked on a 2-year effort in partnership with the local harbor authority to design and develop a working waterfront facility that meets the needs of small-scale fishers and aligns with the existing social and ecological conditions of the area. The vision for this facility is one that both provides the infrastructure and services that small-scale commercial fishers need to sustain their businesses and simultaneously serves as an innovation hub that brings together fishers, researchers, and community leaders to forge solutions to the challenges that threaten the long-term viability of their region's resources and those who depend on them. In this way, it aims to forward both the individual economic goals of fishers and the broader and more complex ecological needs of the local resources. This project was motivated by growing awareness that the loss of working waterfront in North Carolina has the potential to create bottlenecks in the distribution system and undercut the fishing sector's ability to land and sell its catch (Garrity-Blake and Nash 2012). Through this project, WF members have had an opportunity to travel to other parts of the state and country to learn more about how other fishing communities are organizing their operations and sustaining their working waterfronts, e.g., WF members have participated in trips to the Northeast (United States) and California coast as part of a National Fish and Wildlife Foundation Fisheries Innovation Fund grant, sharing experiences and information with other fishers, managers, and seafood industry members. One of the innovative aspects of the proposed design for the facility is for it to serve as a hub for cooperative research among fishers and fisheries scientists and researchers with state, federal, and academic agencies and institutions in the region. It is too early to predict the outcome of this project, but this foray into coastal development and cooperative research demonstrates that WF has moved beyond a marketing initiative and is actively working to address pressing social and ecological issues at the local level. Demonstrating an ability to identify and respond to context-specific issues is vital to adaptive and resilient social-ecological systems (Hughes et al. 2005).

\section{CONCLUSION}

We put forward a qualitative model that begins to sketch out the mechanisms by which CSFs facilitate the production of institutions. These institutions revolve around building, maintaining, and managing bonding and bridging capital and appear to position CSF operators such that they may better respond to social-ecological threats. We give depth to our model by providing a comprehensive analysis of a CSF based in the southeastern United States. We calculate the price premium that fishers in the cooperative received over a 2-year period. These data show that the weighted average price premium across species was $33 \%$. Fishers also received an additional $14 \%$ to $18 \%$ for their catch by way of a year-end dividend. This analysis represents the first detailed economic examination of a CSF in the literature and provides evidence to support the relatively untested assumption that CSFs can offer fishers a way to earn more for their catch. We suggest that this economic benefit is incentivizing cooperation among fishers and resulting in more effective communication with stakeholders outside their immediate community. As a result, fishers are increasing bonding and bridging capital and beginning to leverage it to pursue other opportunities that support the longterm viability of fisheries. In the case of WF, fishers are leveraging their social capital to develop a multipurpose working waterfront facility that they can use as a hub for cooperative research with researchers and fisheries scientists in the region.

Formal cooperation among fishers is not the norm in most U.S. fisheries. Top-down strategies can be used to spur collective action, but without the simultaneous production of social capital, these efforts are unlikely to succeed (Holland et al. 2013). Given this dynamic, we suggest that there is a need to identify and explore emerging and voluntary strategies, such as CSFs, that can facilitate adaptability and ultimately lead to increased general resilience by way of promoting cooperation among resource users. Robust local institutions like these are paramount to resilience in 
social-ecological systems because they can be more attuned to what is happening in particular places and thus can be more responsive to rapid, subtle, and small-scale changes that are difficult to discern at higher levels. Put another way, these institutions can be "alert to learning moments" and thus more capable of being responsive to local disturbances that are caused by such things as fisheries decline, conflict between resource uses, and regional and global market shifts (Westley et al. 2013). Such alertness is critical to identifying, acknowledging, and addressing problems that threaten social-ecological systems.

We refer to these types of entities as institutional starters because they have the potential to create the conditions within which new social networks, rules, and norms can be constructed in places where they did not exist previously. We suggest that the concept of institutional starters has the potential to be helpful in theorizing how systems that are currently "bent out of shape" are transformed and gain (or regain) resilience. More work is needed to more fully develop this concept both in terms of their relationship to direct marketing arrangements and more broadly.

Responses to this article can be read online at: http://www.ecologyandsociety.org/issues/responses. $\mathrm{php} / 7686$

\section{Acknowledgments:}

This article is the outgrowth of a 5-year relationship between the authors of this paper and members of the Walking Fish Cooperative. We would like to express our appreciation to the cooperative for letting us explore their data for this paper. In particular, we thank Debra Callaway and Bill Rice for their insights and perspective. We also thank Jessica Leahy and two anonymous reviewers for their insightful feedback on earlier versions of this manuscript.

\section{LITERATURE CITED}

Abernethy, K. E., Ö. Bodin, P. Olsson, Z. Hilly, and A. Schwarz. 2014. Two steps forward, two steps back: the role of innovation in transforming towards community-based marine resource management in Solomon Islands. Global Environmental Change 28:309-321. http://dx.doi.org/10.1016/j.gloenvcha.2014.07.008

Acheson, J. M. 2003. Capturing the commons: devising institutions to manage the Maine lobster industry. Hanover, NH: University Press of New England.

Acheson, J., and R. Gardner. 2014. Fishing failure and success in the Gulf of Maine: lobster and groundfish management. Maritime Studies 13(1):8. http://dx.doi.org/10.1186/2212-9790-13-8

Ames, E. P. 2004. Atlantic cod stock structure in the Gulf of Maine. Fisheries 29(1):10-28. http://dx.doi.org/10.1577/1548-8446 (2004)29[10:acssit] 2.0.co;2

Barnes-Mauthe, M., S. A. Gray, S. Arita, J. Lynham, and P. Leung. 2015. What determines social capital in a social-ecological system? Insights from a network perspective. Environmental Management 55:392-410. http://dx.doi.org/10.1007/s00267-014-0395-7

Berkes, F. 2009. Evolution of co-management: role of knowledge generation, bridging organizations and social learning. Journal of
Environmental Management 90(5):1692-1702. http://dx.doi. org/10.1016/j.jenvman.2008.12.001

Berkes, F., T. P. Hughes, R. S. Steneck, J. A. Wilson, D. R. Bellwood, B. Crona, C. Folke, L. H. Gunderson, H. M. Leslie, J. Norberg, M. Nyström, P. Olsson, H. Österblom, M. Scheffer, and B. Worm. 2006. Globalization, roving bandits, and marine resources. Science 311(5767):1557-1558. http://dx.doi.org/10.1126/ science. 1122804

Biggs, R., F. R. Westley, and S. R. Carpenter. 2010. Navigating the back loop: fostering social innovation and transformation in ecosystem management. Ecology and Society 15(2): 9. [online] URL: http://www.ecologyandsociety.org/vol15/iss2/art9/

Bodin, Ö., and B. I. Crona. 2009. The role of social networks in natural resource governance: what relational patterns make a difference? Global Environmental Change 19(3):366-374. http:// dx.doi.org/10.1016/j.gloenvcha.2009.05.002

Bodin, Ö., B. Crona, and H. Ernstson. 2006. Social networks in natural resource management: what is there to learn from a structural perspective? Ecology and Society 11(2): r2. [online] URL: http://www.ecologyandsociety.org/vol11/iss2/resp2/

Boucquey, N., L. M. Campbell, G. Cumming, Z. A. Meletis, C. Norwood, and J. Stoll. 2012. Interpreting amenities, envisioning the future: common ground and conflict in North Carolina's rural coastal communities. GeoJournal 77(1):83-101. http://dx.doi. org/10.1007/s10708-010-9387-1

Brewer, J. D. 1994. The ethnographic critique of ethnography: sectarianism in the RUC. Sociology 28(1):231-244. http://dx.doi. org/10.1177/0038038594028001014

Brinson, A., M.-Y. Lee, and B. Rountree. 2011. Direct marketing strategies: the rise of community supported fishery programs. Marine Policy 35(4):542-548. http://dx.doi.org/10.1016/j. marpol.2011.01.014

Campbell, L. M., N. Boucquey, J. Stoll, H. Coppola, and M. D. Smith. 2014. From vegetable box to seafood cooler: applying the community-supported agriculture model to fisheries. Society \& Natural Resources: An International Journal 27(1):88-106. http:// dx.doi.org/10.1080/08941920.2013.842276

Chapin, F. S., III, S. R. Carpenter, G. P. Kofinas, C. Folke, N. Abel, W. C. Clark, P. Olsson, D. M. Stafford Smith, B. Walker, O. R. Young, F. Berkes, R. Biggs, J. M. Grove, R. L. Naylor, E. Pinkerton, W. Steffen, and F. J. Swanson. 2010. Ecosystem stewardship: sustainability strategies for a rapidly changing planet. Trends in Ecology \& Evolution 25(4):241-249. http://dx. doi.org/10.1016/j.tree.2009.10.008

Coleman, J. S 1988. Social capital in the creation of human capital. American Journal of Sociology 94(supplement):S95-S120. http:// dx.doi.org/10.1086/228943

Cooley, J. P., and D. A. Lass. 1998. Consumer benefits from community supported agriculture membership. Applied Economic Perspectives and Policy 20(1):227-237. http://dx.doi. org/10.2307/1349547

Coulthard, S. 2012. Can we be both resilient and well, and what choices do people have? Incorporating agency into the resilience debate from a fisheries perspective. Ecology and Society 17(1): 4. http://dx.doi.org/10.5751/es-04483-170104 
Crowder, L. B., E. L. Hazen, N. Avissar, R. Bjorkland, C. Latanich, and M. B. Ogburn. 2008. The impacts of fisheries on marine ecosystems and the transition to ecosystem-based management. Annual Review of Ecology, Evolution, and Systematics 39:259-278. http://dx.doi.org/10.1146/annurev. ecolsys.39.110707.173406

Cudney-Bueno, R., and X. Basurto. 2009. Lack of cross-scale linkages reduces robustness of community-based fisheries management. PLoS ONE 4(7):e6253. http://dx.doi.org/10.1371/ journal.pone. 0006253

Dahl, R. E., and A. Oglend. 2014. Fish price volatility. Marine Resource Economics 29(4):305-322. http://dx.doi.org/10.1086/678925

Finlayson, C. 1994. Fishing for truth: a sociological analysis of northern cod stock assessments from 1977 to 1990. Institute of Social and Economic Research, Memorial University of Newfoundland, St. John's, Newfoundland, Canada.

Folke, C., S. R. Carpenter, B. Walker, M. Scheffer, T. Chapin, and J. Rockström. 2010. Resilience thinking: integrating resilience, adaptability and transformability. Ecology and Society 15(4): 20. [online] URL: http://www.ecologyandsociety.org/vol15/iss4/ $\underline{\operatorname{art} 20 /}$

Folke, C., T. Hahn, P. Olsson, and J. Norberg. 2005. Adaptive governance of social-ecological systems. Annual Review of Environmental Resources 30:441-473. http://dx.doi.org/10.1146/ annurev.energy.30.050504.144511

Folke, C., L. Pritchard, F. Berkes, J. Colding, and U. Svedin. 2007. The problem of fit between ecosystems and institutions: ten years later. Ecology and Society 12(1): 30. [online] URL: http://www. ecologyandsociety.org/vol12/iss1/art30/

Frank, K. T., B. Petrie, J. A. D. Fisher, and W. C. Leggett. 2011. Transient dynamics of an altered large marine ecosystem. Nature 477(7362):86-89. http://dx.doi.org/10.1038/nature10285

Freitag, A., N. Sohn, M. Hooper, and D. Rittschof. 2012. The geography of mercury and PCBs in North Carolina's local seafood. Marine Pollution Bulletin 64(7):1330-1338. http://dx.doi. org/10.1016/j.marpolbul.2012.05.003

Garcia, S. M., and A. A. Rosenberg. 2010. Food security and marine capture fisheries: characteristics, trends, drivers and future perspectives. Philosophical Transactions of the Royal Society B: Biological Sciences 365(1554):2869-2880. http://dx.doi.org/10.1098/ rstb.2010.0171

Garrity-Blake, B., and B. Nash. 2012. An inventory of North Carolina fish houses: five-year update. UNC-SG-12-06. North Carolina Sea Grant, Morehead City, North Carolina, USA.

Gelcich, S., P. Buckley, J. K. Pinnegar, J. Chilvers, I. Lorenzoni, G. Terry, M. Guerrero, J. C. Castilla, A. Valdebenito, and C. M. Duarte. 2014. Public awareness, concerns, and priorities about anthropogenic impacts on marine environments. Proceedings of the National Academy of Sciences of the United States of America 111(42):15042-15047. http://dx.doi.org/10.1073/pnas. 1417344111

Greenberg, P. 2014. American catch: the fight for our local seafood. Penguin, New York, New York, USA.

Greenwood, R., R. Suddaby, and C. R. Hinings. 2002. Theorizing change: the role of professional associations in the transformation of institutionalized fields. Academy of Management Journal 45 (1):58-80. http://dx.doi.org/10.2307/3069285

Gutiérrez, N. L., R. Hilborn, and O. Defeo. 2011. Leadership, social capital and incentives promote successful fisheries. Nature 470(7334):386-389. http://dx.doi.org/10.1038/nature09689

Hennessey, T., and M. Healey. 2000. Ludwig's ratchet and the collapse of New England groundfish stocks. Coastal Management 28(3):187-213. http://dx.doi.org/10.1080/089207500408629

Hilborn, R. 2012. The evolution of quantitative marine fisheries management 1985-2010. Natural Resource Modeling 25 (1):122-144. http://dx.doi.org/10.1111/j.1939-7445.2011.00100.x

Holland, D. S., A. W. Kitts, P. Pinto da Silva, and J. Wiersma. 2013. Social capital and the success of harvest cooperatives in the New England groundfish fishery. Marine Resource Economics 28 (2):133-153. http://dx.doi.org/10.5950/0738-1360-28.2.133

Holling, C. S., and L. H. Gunderson. 2002. Resilience and adaptive cycles. Pages 25-62 in L. H. Gunderson and C. S. Holling, editors. Panarchy: understanding transformations in human and natural systems. Island, Washington, D.C., USA.

Hughes, T. P., D. R. Bellwood, C. Folke, R. S. Steneck, and J. Wilson. 2005. New paradigms for supporting the resilience of marine ecosystems. Trends in Ecology \& Evolution 20(7):380-386. http://dx.doi.org/10.1016/j.tree.2005.03.022

Jackson, J. B. C., M. X. Kirby, W. H. Berger, K. A. Bjorndal, L. W. Botsford, B. J. Bourque, R. H. Bradbury, R. Cooke, J. Erlandson, J. A. Estes, T. P. Hughes, S. Kidwell, C. B. Lange, H. S. Lenihan, J. M. Pandolfi, C. H. Peterson, R. S. Steneck, M. J. Tegner, and R. R. Warner. 2001. Historical overfishing and the recent collapse of coastal ecosystems. Science 293(5530):629-637. http://dx.doi.org/10.1126/science.1059199

Kasperski, S., and D. S. Holland. 2013. Income diversification and risk for fishermen. Proceedings of the National Academy of Sciences of the United States of America 110(6):2076-2081. http:// dx.doi.org/10.1073/pnas. 1212278110

Kloppenburg, J., Jr., J. Hendrickson, and G. W. Stevenson. 1996. Coming in to the foodshed. Agriculture and Human Values 13 (3):33-42. http://dx.doi.org/10.1007/bf01538225

Le Cornu, E., J. N. Kittinger, J. Z. Koehn, E. M. Finkbeiner, and L. B. Crowder. 2014. Current practice and future prospects for social data in coastal and ocean planning. Conservation Biology 28(4):902-911. http://dx.doi.org/10.1111/cobi.12310

Levin, S. 2007. Fragile dominion. Basic Books, New York, New York, USA.

Libby, R. 2011. An abundant food system. Maine Policy Review 20(1):61-65.

Lin, N. 2002. Social capital: a theory of social structure and action (structural analysis in the social sciences). Social Forces 82 (3):1209-1211.

LocalCatch.org. 2014. Community supported fisheries. LocalCatch.org. [online] URL: http://www.localcatch.org/

Lowe, M., and C. Carothers, editors. 2008. Enclosing the fisheries: people, places, and power. Symposium 68, American Fisheries Society, Bethesda, Maryland, USA. 
Maguire, S., C. Hardy, and T. B. Lawrence. 2004. Institutional entrepreneurship in emerging fields: HIV/AIDS treatment advocacy in Canada. Academy of Management Journal 47 (5):657-679. http://dx.doi.org/10.2307/20159610

McCarthy, D. D. P., G. S. Whitelaw, F. R. Westley, D. D. Crandall, and D. Burnett. 2014. The Oak Ridges Moraine as a social innovation: strategic vision as a social-ecological interaction. Ecology and Society 19(1): 48. http://dx.doi.org/10.5751/ ES-06212-190148

McCay, B. J. 2002. Emergence of institutions for the commons: contexts, situations, and events. Pages 361-402 in E. Ostrom, T. Dietz, N. Dolšak, P. C. Stern, S. Stovich, and E. U. Weber, editors. The drama of the commons. National Academy, Washington, D. C., USA.

McClenachan, L., B. P. Neal, D. Al-Abdulrazzak, T. Witkin, K. Fisher, and J. N. Kittinger. 2014. Do community supported fisheries (CSFs) improve sustainability? Fisheries Research 157:62-69. http://dx.doi.org/10.1016/j.fishres.2014.03.016

National Summit Planning Committee. 2012. National summit on community supported fisheries: building a network, identifying challenges and opportunities, \& defining next steps. Final Report, Needs Assessment, and Recommendations. LocalCatch.org. [online] URL: http://www.localcatch.org/wp-content/uploads/2015/04/ Summit_Report.pdf

Newman, L., and A. Dale. 2007. Homophily and agency: creating effective sustainable development networks. Environment, Development and Sustainability 9(1):79-90. http://dx.doi. org/10.1007/s10668-005-9004-5

O'Hara, S. U., and S. Stagl. 2001. Global food markets and their local alternatives: a socio-ecological economic perspective. Population and Environment 22(6):533-554. http://dx.doi. org/10.1023/A:1010795305097

Olson, J. 2011. Understanding and contextualizing social impacts from the privatization of fisheries: an overview. Ocean \& Coastal Management 54(5):353-363. http://dx.doi.org/10.1016/j. ocecoaman.2011.02.002

Olson, J., P. M. Clay, and P. Pinto da Silva. 2014. Putting the seafood in sustainable food systems. Marine Policy 43:104-111. http://dx.doi.org/10.1016/j.marpol.2013.05.001

Olsson, P., C. Folke, and T. Hahn. 2004. Social-ecological transformation for ecosystem management: the development of adaptive co-management of a wetland landscape in southern Sweden. Ecology and Society 9(4): 2. [online] URL: http://www. ecologyandsociety.org/vo19/iss4/art2/

Ostrom, E. 1990. Governing the commons: the evolution of institutions for collective action. Cambridge University Press, Cambridge, UK. http://dx.doi.org/10.1017/cbo9780511807763

Perez, J., P. Allen, and M. Brown. 2003. Community supported agriculture on the Central Coast: the CSA member experience. Research Brief No. 1. The Center for Agroecology \& Sustainable Food Systems, University of California, Santa Cruz, Santa Cruz, California, USA.

Pramod, G., K. Nakamura, T. J. Pitcher, and L. Delagran. 2014. Estimates of illegal and unreported fish in seafood imports to the
USA. Marine Policy 48:102-113. http://dx.doi.org/10.1016/j. marpol.2014.03.019

Pretty, J., and D. Smith. 2004. Social capital in biodiversity conservation and management. Conservation Biology 18 (3):631-638. http://dx.doi.org/10.1111/j.1523-1739.2004.00126.x

Pretty, J., and H. Ward. 2001. Social capital and the environment. World Development 29(2):209-227. http://dx.doi.org/10.1016/ $\underline{\mathrm{s} 0305-750 \mathrm{x}(00) 00098-\mathrm{x}}$

Putnam, R. D. 1995. Bowling alone: America's declining social capital. Journal of Democracy 6:65-78. http://dx.doi.org/10.1353/ jod.1995.0002

Rosen, F., and P. Olsson. 2013. Institutional entrepreneurs, global networks, and the emergence of international institutions for ecosystem-based management: the Coral Triangle Initiative. Marine Policy 38:195-204. http://dx.doi.org/10.1016/j.marpol.2012.05.036

Steneck, R. S., T. P. Hughes, J. E. Cinner, W. N. Adger, S. N. Arnold, F. Berkes, S. A. Boudreau, K. Brown, C. Folke, L. Gunderson, P. Olsson, M. Scheffer, E. Stephenson, B. Walker, J. Wilson, and B. Worm. 2011. Creation of a gilded trap by the high economic value of the Maine lobster fishery. Conservation Biology 25(5):904-912. http://dx.doi.org/10.1111/j.1523-1739.2011.01717. $\underline{x}$

Steneck, R. S., A. Leland, D. C. McNaught, and J. Vavrinec. 2013. Ecosystem flips, locks, and feedbacks: the lasting effects of fisheries on Maine's kelp forest ecosystem. Bulletin of Marine Science 89(1):31-55. http://dx.doi.org/10.5343/bms.2011.1148

Stoll, J., A. Baldera, K. Gordon, and N. Mallos. 2010. Walking Fish: steps towards a viable future in small-scale fisheries. Walking Fish, Beaufort, North Carolina, USA. [online] URL: http://www. localcatch.org/Walking Fish Report 2009.pdf

Stoll, J. S., and T. R. Johnson. 2015. Under the banner of sustainability: the politics and prose of an emerging US federal seafood certification. Marine Policy 51:415-422. http://dx.doi. org/10.1016/j.marpol.2014.09.027

Tietze, U., and L. V. Villareal. 2003. Microfinance in fisheries and aquaculture: guidelines and case studies. Food and Agriculture Organization of the United Nations (FAO) Fisheries Technical Paper 440. FAO, Rome, Italy.

Walker, B., C. S. Holling, S. R. Carpenter, and A. Kinzig. 2004. Resilience, adaptability and transformability in social-ecological systems. Ecology and Society 9(2): 5. [online] URL: http://www. ecologyandsociety.org/vo19/iss2/art5/

Westley, F. 1995. Governing design: the management of social systems and ecosystems management. Pages 391-427 in L. H. Gunderson, C. S. Holling, and S. S. Light, editors. Barriers and bridges to the renewal of ecosystems and institutions. Columbia University Press, New York, New York, USA.

Westley, F., P. Olsson, C. Folke, T. Homer-Dixon, H. Vredenburg, D. Loorbach, J. Thompson, M. Nilsson, E. Lambin, J. Sendzimir, B. Banerjee, V. Galaz, and S. Van der Leeuw. 2011. Tipping toward sustainability: emerging pathways of transformation. AMBIO 40 (7):762-780. http://dx.doi.org/10.1007/s13280-011-0186-9

Westley, F. R., O. Tjornbo, L. Schultz, P. Olsson, C. Folke, B. Crona, and Ö. Bodin. 2013. A theory of transformative agency 
in linked social-ecological systems. Ecology and Society 18(3): 27. http://dx.doi.org/10.5751/es-05072-180327

Wijen, F., and S. Ansari. 2007. Overcoming inaction through collective institutional entrepreneurship: insights from regime theory. Organization Studies 28(7):1079-1100. http://dx.doi. org/10.1177/0170840607078115

Wilson, J. A. 1980. Adaptation to uncertainty and small numbers exchange: the New England fresh fish market. Bell Journal of Economics 11(2):491-504. http://dx.doi.org/10.2307/3003375

Wilson, J. A., J. M. Acheson, and T. R. Johnson. 2013. The cost of useful knowledge and collective action in three fisheries. Ecological Economics 96:165-172. http://dx.doi.org/10.1016/j. ecolecon.2013.09.012

Woolcock, M., and D. Narayan. 2000. Social capital: implications for development theory, research, and policy. World Bank Research Observer 15(2):225-249. http://dx.doi.org/10.1093/ $\underline{w b r o} / 15.2 .225$

Yin, R. K. 1984. Case study research: design and methods. Sage, Beverly Hills, California, USA.

Young, O. 2002. The institutional dimensions of environmental change: fit, interplay, and scale. MIT Press, Cambridge, Massachusetts, USA.

Yu, D., J. M. Anderies, D. Lee, and I. Perez. 2014. Transformation of resource management institutions under globalization: the case of songgye community forests in South Korea. Ecology and Society 19(2): 2. http://dx.doi.org/10.5751/es-06135-190202

Zhou, S., A. D. M. Smith, and E. E. Knudsen. In press. Ending overfishing while catching more fish. Fish and Fisheries. http://dx. doi.org/10.1111/faf.12077 